\title{
Desain Sistem Manajemen Risiko pada Perguruan Tinggi Negeri Badan Hukum (PTN BH) Studi Kasus pada Universitas Gadjah Mada
}

\author{
Mukhlis $^{\mathrm{a}^{*},}$ Supriyadi ${ }^{\mathrm{b}}$ \\ ${ }^{a}$ Auditor Muda di Kantor Audit Internal, Universitas Gadjah Mada, mukhlis.ginting@gmail.com, Indonesia \\ ${ }^{\mathrm{b}}$ Universitas Gadjah Mada, Indonesia
}

\begin{abstract}
Penelitian ini membahas desain sistem manajemen risiko yang dapat diterapkan pada Perguruan Tinggi Negeri Badan Hukum (PTN BH) dengan studi kasus pada Universitas Gadjah Mada (UGM). Penelitian ini menggunakan metode kualitatif deskriptif dengan studi kasus pada UGM. Penelitian mendeskripsikan dan menganalisis desain sistem manajemen risiko yang sebaiknya dijalankan oleh UGM dengan menggunakan teknik wawancara dan dokumentasi dalam pengumpulan data. Data dianalisis menggunakan interactive model, meliputi pengumpulan data, reduksi data, penyajian data, dan simpulan atau verifikasi. Penelitian menyimpulkan bahwa manajemen risiko telah berjalan di UGM, meskipun belum terstruktur dan sistematis. Oleh karena itu, UGM perlu membentuk struktur, proses, dan prosedur manejemen risiko. Struktur manajemen risiko dapat menggunakan model tiga tingkatan pengendalian; tingkat kebijakan dijalankan oleh Komite Audit, tingkat operasional dijalankan oleh rektor dibantu oleh Kantor Audit Internal dan Kantor Jaminan Mutu sebagai koordinator proses manajemen risiko yang dilakukan oleh unit kerja; tingkat pengawasan dilakukan oleh Komite Audit. Proses manajemen risiko dapat menggunakan standar proses manajemen risiko AS/NZS 31000:2009 yang terdiri atas proses penetapan konteks, identifikasi risiko, analisis risiko, evaluasi risiko, penanganan risiko, pemantauan dan review, dan komunikasi serta konsultasi. Prosedur manajemen risiko dapat disusun berdasarkan periode tujuan UGM yang terdiri dari periode lima tahunan, satu tahunan, dan periode waktu tertentu.
\end{abstract}

Keywords: Perguruan Tinggi Negeri Badan Hukum, PTN BH, risiko, manajemen risiko, proses manajemen risiko, prosedur manajemen risiko, struktur manajemen risiko

\section{Pendahuluan}

Perguruan Tinggi Negeri Badan Hukum (PTN BH) adalah perguruan tinggi negeri yang didirikan oleh pemerintah dan berstatus sebagai badan hukum publik yang otonom, baik dalam bidang akademik maupun nonakademik. Otonomi PTN BH diatur dalam Undang-Undang Nomor 12 Tahun 2012 tentang Pendidikan Tinggi pasal 64. Sampai tanggal 31 Desember 2015, pemerintah telah menetapkan 11 perguruan tinggi sebagai PTN BH.

Perguruan Tinggi Negeri Badan Hukum (PTN BH) perlu menerapkan manajemen risiko setidaknya disebabkan oleh tiga hal. Pertama, aturan pemerintah yang mewajibkan penerapannya, Kedua, penerapan manajemen risiko membantu PTN $\mathrm{BH}$ dalam mencapai tujuan organisasi. Ketiga, perubahan status pengelolaan perguruan tinggi dari PTN satuan kerja pemerintah menjadi PT Badan Hukum Milik Negara (PT BHMN), selanjutnya menjadi PTN dengan Pola Pengelolaan Keuangan Badan Layanan Umum (PTN PPK BLU) dan saat ini sebagai PTN BH menimbulkan risiko yang perlu dikelola.

Pemerintah mengharuskan PTN BH menyelenggarakan manajemen risiko sebagai bagian dari penyelenggaraan Sistem Pengendalian Intern

*Corresponding author. E-mail: mukhlis.ginting@gmail.com 
Pemerintah (SPIP) sebagaimana ditetapkan dalam Peraturan Pemerintah Nomor 60 Tahun 2008 (PP No. 60 Tahun 2008) tentang SPIP. PP No. 60 Tahun 2008 Pasal 1 angka 2 menyebutkan, "Sistem pengendalian intern pemerintah, selanjutnya disingkat SPIP, adalah sistem pengendalian intern yang diselenggarakan secara menyeluruh di lingkungan pemerintah pusat dan pemerintah daerah". PTN BH merupakan instansi vertikal, berada di bawah pemerintah pusat, Kementerian Riset Teknologi dan Pendidikan Tinggi (Kemenristekdikti). SPIP terdiri atas lima unsur mencakupi (1) lingkungan pengendalian, (2) penilaian risiko, (3) kegiatan pengendalian, (4) informasi dan komunikasi, serta (5) pemantauan. Unsur penilaian risiko meliputi aktivitas identifikasi risiko dan analisis risiko. Unsur penilaian risiko dikenal juga dengan istilah manajemen risiko.

\begin{tabular}{cll}
\multicolumn{4}{c}{ Tabel 1 Daftar PTN BH dan Penetapannya } \\
\hline No & \multicolumn{1}{c}{ Universitas } & Ditetapkan Berdasarkan \\
\hline 1. & Institut Teknologi Bandung (ITB) & UU Nomor 12 Tahun 2012 \\
2. & Universitas Gadjah Mada (UGM) & UU Nomor 12 Tahun 2012 \\
3. & Institut Pertanian Bogor (IPB) & UU Nomor 12 Tahun 2012 \\
4. & Universitas Indonesia (UI) & UU Nomor 12 Tahun 2012 \\
5. & Universitas Pendidikan Indonesia (UPI) & UU Nomor 12 Tahun 2012 \\
6. & Universitas Sumatera Utara (USU) & UU Nomor 12 Tahun 2012 \\
7. & Universitas Airlangga (Unair) & UU Nomor 12 Tahun 2012 \\
8. & Universitas Padjajaran (Unpad) & PP Nomor 51 Tahun 2015 \\
9. & Universitas Diponegoro (Undip) & PP Nomor 52 Tahun 2015 \\
10. & Universitas Hasanudin (Unhas) & PP Nomor 53 Tahun 2015 \\
11. & Institut Teknologi Surabaya (ITS) & PP Nomor 54 Tahun 2015 \\
\hline
\end{tabular}

Penerapan manajemen risiko akan membantu PTN BH dalam mencapai tujuan organisasi. Proses dasar manajemen risiko meliputi identifikasi risiko, penilaian risiko, prioritas risiko dan perencanaan respon, dan pemantauan risiko (Moeller, 2011). Manajemen risiko bermanfaat bagi PTN BH dalam mengidentifikasi area risiko utama yang dihadapi dan pengelolaan risiko tersebut akan membantu PTN BH dalam mencapai indikator kinerja utama (Helsloot dan Jong, 2006; Tufano, 2011). Pelaksanaan manajemen risiko mampu meminimalisir probabilitas dan atau konsekuensi dari kejadian tidak menguntungkan. Selain itu, manajemen risiko dapat meningkatkan kesadaran manajemen PTN BH terhadap risiko dalam pengambilan keputusan strategis dan operasional (Hoyt dan Liebenberg, 2010).

Perubahan status pengelolaan PT, khususnya UGM, menimbulkan risiko yang perlu dikelola. UGM merupakan salah satu dari PTN yang ditetapkan sebagai PTN BH dalam UU Nomor 12 Tahun 2012. UGM berdiri pada 19 Desember 1949 di Yogyakarta. Sebelum tahun 2001, UGM berstatus sebagai satuan kerja pemerintah. Pada tahun 2001 status UGM berubah menjadi PT BHMN, ditetapkan dalam
Peraturan Pemerintah (PP) Nomor 153 Tahun 2000. Status UGM sebagai PT BHMN berlangsung selama 13 tahun hingga terbit dan berlakunya PP Nomor 74 Tahun 2012, menetapkan UGM sebagi PTN PPK BLU. Status tersebut hanya berlangsung singkat karena Undang-Undang Nomor 12 Tahun 2012 menetapkan UGM sebagai PTN BH, mulai berlaku efektif per tanggal 10 Agustus 2014.

Perubahan status sebagaimana dijelaskan di atas, khususnya dari PTN PPK BLU menjadi PTN BH, berdampak pada perubahan pola pengelolaan universitas, khususnya terhadap aset dan keuangan. Peralihan status BMN yang selama ini dimiliki oleh UGM sebagai PTN PPK BLU menjadi Barang Milik Universitas (BMU), kecuali tanah, membutuhkan aturan pengelolaan aset yang memadai, mulai dari peroses pengadaan, penggunaan, perawatan, pemanfaatan, pencatatan, hingga penggunaan sistem informasi manajemen aset. Hal ini menimbulkan risiko pengadaan barang tidak efisien, kerusakan dan kehilangan aset, serta catatan aset menjadi tidak handal. Perubahan sifat dana yang diterima dari PNBP menjadi non-PNBP memberikan keleluasaan bagi UGM dalam mengelola dana tersebut secara otonom. Perubahan tersebut membutuhkan aturan dan pengendalian pengelolaan keuangan yang baru, ini menimbulkan risiko inefisiensi penggunaan dana sejak penganggaran hingga realisasinya.

Risiko di atas dapat dicegah sebelum terjadi atau ditangani jika telah terjadi dengan manajemen risiko. Risiko adalah kemungkinan terjadinya suatu peristiwa yang dapat mengakibatkan dampak berupa kerugian atau kegagalan dalam pencapaian tujuan organisasi (Griffiths, 2005; IRM dan AIRMIC, 2002; AS/NZS ISO 31000:2009, 2009; GOWA, 2007). Adapun manajemen risiko adalah sistem atau proses yang dilakukan oleh personel di setiap level organisasi untuk mengidentifikasi dan mengelola risiko guna menjamin pencapaian tujuan organisasi (Rejda, 2006; Hanafi, 2006; GOWA, 2007; Moeller, 2007; Thomas. 2010; $\quad$ Ariff dkk., 2014). Dengan mengimplementasikan manajemen risiko, PTN BH dapat mengidentifikasi risiko, dampak hambatannya terhadap pencapaian tujuan dan sasaran PTN BH, dan memilih serta menyiapkan cara paling tepat untuk mengatasi hal tersebut.

UGM telah memiliki kesadaran akan pentingnya manajemen risiko, meskipun belum menerapkannya secara menyeluruh. Kesadaran risiko terlihat dari penggunaan pendekatan probity audit dalam proses pengadaan barang dan jasa. Kantor Audit Internal (KAI) UGM melakukan audit pada proses pengadaan barang/jasa sejak proses perencanaan, pelaksanaan, 
hingga pemeliharaan. Meskipun demikian, UGM belum menerapkan pengelolaan risiko yang meliputi seluruh unit kerja dan aktivitas di universitas. Berdasarkan hal-hal di atas maka pertanyaan penelitian ini adalah:

a. Siapa saja yang sebaiknya terlibat dalam sistem manajemen risiko UGM dan apa fungsi masingmasing pihak tersebut?

b. Bagaimana proses manajemen risiko yang sebaiknya dijalankan oleh UGM?

c. Bagaimana prosedur manajemen risiko yang sebaiknya dijalankan oleh UGM?

\section{Tinjauan Pustaka}

\section{Risiko dan Manajemen Risiko}

Terdapat beberapa definisi risiko yang dikemukakan oleh berbagai pihak. Menurut Griffiths (2005), risiko adalah ancaman bahwa suatu tindakan atau peristiwa buruk akan memengaruhi kemampuan organisasi untuk mencapai tujuan dan melaksanakan strategi yang berhasil. Menurut The Institute of Risk Management (IRM) dan The Association of Insurance and Risk Managers (AIRMIC) (2002), risiko adalah peluang terjadinya sesuatu, mempunyai dampak terhadap tujuan. Sedangkan menurut Australian New Zealand International Standard (AS/NZS ISO 31000:2009) dan Pedoman Teknis Penyelenggaraan Sistem Pengendalian Intern Pemerintah (SPIP) (2009), risiko adalah kemungkinan kejadian yang mengancam pencapaian tujuan dan sasaran instansi pemerintah. Berdasarkan definisi-definisi tersebut dapat disimpulkan bahwa risiko adalah suatu kejadian yang merupakan kemungkinan yang bila terjadi akan dapat menghambat pencapaian tujuan organisasi.

Terdapat 4 tahap proses manajemen risiko yang mendasar (Moeller, 2007), terdiri atas (1) identifikasi risiko, (2) penilaian risiko, (3) prioritas risiko dan perencanaan respon, serta (4) pemantauan risiko. Identifikasi risiko menghasilkan daftar risiko potensial. Pengukuran risiko memberi informasi tentang kemungkinan terjadinya dan dampak yang ditimbulkan jika risiko terjadi. Prioritas risiko dan perencanaan respon merupakan tindak lanjut yang perlu dilakukan oleh manajemen untuk melakukan tindakan atas setiap risiko yang ada berdasarkan prioritas dan kecenderungan risiko.

\section{Manajemen Risiko pada Instansi Pemerintah}

Manajemen risiko pada instansi pemerintah Indonesia diatur dalam PP No. 60 Tahun 2008 tentang Sistem Pengendalian Intern Pemerintah (SPIP). Manajemen risiko menjadi salah satu dari lima unsur SPIP, yaitu unsur penilaian risiko. PP No. 60 Tahun 2008 menetapkan BPKP sebagai pembina penyelenggaraan SPIP.

BPKP mendorong seluruh instansi pemerintah agar menyelenggarakan SPIP dan manajemen risiko, salah satunya Kementerian Keuangan. Kementerian Keuangan merupakan salah satu contoh instansi pemerintah yang telah menyelenggarakan SPIP, khususnya manajemen risiko dengan terstruktur dan sistematis. Dikatakan terstruktur karena telah menata struktur organisasi dengan menjalankan manajemen. Dikatakan sistematis karena telah menggunakan kerangka kerja (frame work) proses manajemen risiko.

Kementerian Keuangan menerbitkan Peraturan Menteri Keuangan Nomor 191/PMK.09/2008 tentang Penerapan Manajemen Risiko di Lingkungan Depertemen Keuangan. Terdapat 5 unsur utama dalam penerapan manajemen risiko di Kementerian Keuangan, yaitu (1) piagam manajemen risiko, (2) struktur manajemen risiko, (3) strategi penerapan manajemen risiko, (4) proses manajemen risiko, dan (5) pelaporan risiko.

Manajemen risiko di Departemen Keuangan mengadopsi model tiga tingkat pengendalian, terdiri atas pengendalian tingkat kebijakan, pengendalian tingkat operasional, dan pengawasan pengendalian. Pengendalian tingkat kebijakan bertanggung jawab dalam mengooridinasikan, memfasilitasi, serta mengawasi efektivitas dan integritas proses manajemen risiko. Pengendalian tingkat kebijakan dilakukan oleh komite manajemen risiko. Pengendalian tingkat operasional bertanggung jawab langsung atas pengelolaan dan pengendalian risiko sehari-hari. Pengendalian tingkat operasional dilaksanakan oleh ketua manajemen risiko dan unit pemilik risiko. Tingkat pengawasan pengendalian berfungsi memberikan penilaian independen atas efektivitas pelaksanaan manajemen risiko di seluruh jajaran eselon I kepada stakeholder terkait, dilaksanakan oleh Inspektorat Jenderal dan auditor eksternal.

Proses manajemen risiko yang diterapkan di Departemen Keuangan diadobsi dari kerangka Australia/New Zealand (AS/NZS) ISO 31000:2009, merupakan standar manajemen risiko yang diterbitkan oleh Australia dan Selandia Baru, berisi 7 elemen 
yaitu: penetapan konteks, identifikasi risiko, analisis risiko, evaluasi risiko, penanganan risiko, pemantauan dan review, komunikasi dan konsultasi.

Unit eselon I membuat laporan profil risiko dan peta risiko, berisi tingkat dan tren seluruh paparan risiko yang relevan, disajikan bersama dengan profil serta peta risiko pada semester sebelumnya agar dapat dibandingkan. Laporan tersebut disampaikan secara berkala per semester kepada Menteri Keuangan. Sistem informasi dan teknologi informasi yang digunakan oleh unit eselon I didesain sedemikian rupa sehingga dapat menyediakan informasi pelaksanaan manajemen risiko.

\section{Metode Penelitian}

Penelitian ini menggunakan metode kualitatif deskriptif dengan studi kasus pada UGM sebagai PTN BH. Penelitian mendeskripsikan dan menganalisis desain prosedur manajemen risiko yang sebaiknya dijalankan oleh UGM.

Data yang dikumpulkan adalah data primer dan data sekunder. Data primer berupa hasil wawancara, Data sekunder berupa peraturan perundangan yang berlaku, peraturan MWA, peraturan atau surat keputusan Rektor UGM, surat edaran, dan dokumen lain yang relevan.

Untuk memperoleh gambaran mengenai proses manajemen risiko yang saat ini berjalan di UGM dan bagaimana proses ideal yang sebaiknya dilakukan UGM, peneliti menggunakan teknik wawancara dan dokumentasi. Wawancara berupa wawancara semitersruktur kepada 6 pejabat struktural yaitu; (1) Wakil Rektor Bidang Perencanaan, Keuangan dan Sistem Informasi, (2) Direktur Keuangan, (3) Kepala Subdirektorat Sarana Direktorat Aset, (4) Kepala Seksi Pendayagunaan, Penghapusan, Pengawasan, dan Pengendalian Aset (P4A) Direktorat Aset, (5) Kepala Bagian Konsultasi dan Pengembangan Kantor Audit Internal, dan (6) Wakil Dekan Bidang Keuangan, Aset, dan Sumber Daya Manusia Fakultas Ekonomika dan Bisnis. Sampel dipilih dengan mempertimbangkan keterwakilan unsur pimpinan, unsur pelaksana akademik, serta unsur pelaksana administrasi dan pengembangan.

Dokumentasi yang diperlukan dalam penelitian ini meliputi informasi terkait profil UGM, peraturan dan informasi terkait, dan manajemen risiko. Data profil UGM, mencakup sejarah singkat, visi, misi, tujuan, sasaran, tugas, fungsi, dan struktur organisasi. Data peraturan dan informasi terkait meliputi peraturan pemerintah, peraturan menteri, peraturan rektor, catatan, transkrip, buku dan pedoman, surat kabar daring, majalah, serta dokumentasi lainnya yang relevan. Data manajemen risiko meliputi Rencana Strategis (Renstra), Rencana Operasional (Renop), kontrak kinerja antara UGM dengan Kemenristekdikti, dan data lainnya yang relevan.

Penelitian ini menggunakan interactive model dalam analisis data hasil wawancara. Interactive model menggunakan 4 komponen, yaitu (1) pengumpulan data, (2) reduksi data, (3) penyajian data, dan (4) simpulan atau verifikasi (Miles dan Huberman, 1984; Sugiyono, 2007).

Pengumpulan data dilakukan melalui wawancara dan dokumentasi. Wawancara dilakukan dengan personal interview, yaitu wawancara tatap muka langsung dengan responden (Jogiyanto, 2004). Hasil wawancara direkam dengan alat perekam dan disalin dalam bentuk transkrip.

Reduksi data dilakukan dengan kodefikasi dan axial coding atas hasil wawancara. Data yang diperoleh dari wawancara disalin dalam bentuk transkrip, ditelaah dan diberi kode tertentu pada setiap frasa, kalimat, atau paragraf berdasarkan topik. Data yang diberi kode tersebut dikelompokkan ke dalam kategori tertentu, kemudian dicari hubungan antarkategori (axial coding). Proses reduksi data dilakukan terus-menerus selama penelitian berlangsung. Hasil reduksi data disajikan dalam Lampiran 1.

Penyajian data dilakukan dengan narasi dan flowchart untuk mengorganisasikan data. Data yang telah direduksi, disajikan dalam bentuk narasi dan flowchart (diagram alur), menggambarkan proses manajemen risiko di UGM. Melalui penyajian data dengan narasi dan diagram alur tersebut, data akan terorganisasikan, tersusun dalam pola hubungan, sehingga mudah dipahami.

Penarikan simpulan dan verifikasi dilakukan berdasarkan proses reduksi dan penyajian data. Simpulan didukung oleh bukti-bukti valid dan konsisten selama proses penelitian berlangsung. Simpulan akan menjawab rumusan masalah yang ditetapkan sejak awal.

\section{Hasil dan Pembahasan}

Berdasarkan statuta PTN BH sebagaimana disajikan pada Tabel 2, seluruh PTN BH memiliki organ dan unit kerja yang sama dalam konteks manajemen risiko, kecuali Universitas Indonesia. Seluruh PTN BH memiliki organ MWA, SA, dan 
rektor. Seluruh PTN BH juga memiliki komite audit yang menjadi perangkat MWA dalam melakukan pengawasan bidang nonakademik. Seluruh PTN BH memiliki unit kerja yang melaksanakan fungsi audit atau pengawasan internal dan unit kerja yang melaksanakan fungsi penjaminan mutu akademik. Data memperlihatkan hanya UI yang memiliki komite manajemen risiko. Meskipun PTN BH selain UI tidak memiliki komite manajemen risiko, namun fungsi tersebut dijalankan oleh komite audit.

\begin{tabular}{lccccccc}
\multicolumn{8}{c}{ Tabel 2 Organ dan Struktur Organisasi PTN BH } \\
\hline No. PTN & MWA & SA & Rektor & KA & KR $^{*}$ & UAI $^{* *}$ & UPM $^{* * *}$ \\
\hline 1. UI & Ada & Ada & Ada & Ada & Ada & Ada & Ada \\
2. ITB & Ada & Ada & Ada & Ada & Tidak & Ada & Ada \\
3. UGM & Ada & Ada & Ada & Ada & Tidak & Ada & Ada \\
4. IPB & Ada & Ada & Ada & Ada & Tidak & Ada & Ada \\
5. UPI & Ada & Ada & Ada & Ada & Tidak & Ada & Ada \\
6. USU & Ada & Ada & Ada & Ada & Tidak & Ada & Ada \\
7. Unair & Ada & Ada & Ada & Ada & Tidak & Ada & Ada \\
8. Unpad & Ada & Ada & Ada & Ada & Tidak & Ada & Ada \\
9. Undip & Ada & Ada & Ada & Ada & Tidak & Ada & Ada \\
10. Unhas & Ada & Ada & Ada & Ada & Tidak & Ada & Ada \\
11. ITS & Ada & Ada & Ada & Ada & Tidak & Ada & Ada
\end{tabular}

*komite risiko.

**unit kerja yang melaksanakan fungsi audit atau pengawasan internal. ***unit kerja yang melaksanakan fungsi penjaminan mutu akademik.

Statuta masing-masing PTN BH telah menetapkan tugas KA yang bersinggungan atau beririsan dengan manajemen risiko. Analisis atas statuta PTN BH khususnya tentang manajemen risiko dan tugas KA disajikan dalam Lampiran 2.

\section{a. Kondisi Manajemen Risiko yang Saat ini Berjalan di UGM}

Manajemen risiko telah berjalan dan embedded dalam proses bisnis UGM, hal ini dapat dilihat dari adanya kesadaran akan risiko dalam pengambilan keputusan dan perancangan sistem. Selain itu, proses manajemen risiko telah berjalan di UGM, bahkan beberapa unit kerja melakukan proses manajemen risiko tersebut, meskipun belum terstruktur dan sistematis.

b. Sistem Manajemen Risiko yang Sebaiknya Diterapkan di UGM

Sistem manjemen risiko yang sebaiknya diterapkan di UGM meliputi (1) struktur organisasi manajemen risiko, (2) proses manajemen risiko, dan (3) prosedur manajemen risiko.

\section{Struktur Manajemen Risiko UGM}

Dalam melaksanakan proses manajemen risiko, dibutuhkan organisasi personel pelaksana, tergambar dalam struktur manajemen risiko. Struktur manajemen risiko UGM dapat mengadopsi model tiga tingkatan pengendalian sesuai dengan struktur organisasi yang tertuang dalam PP 67 Tahun 2013 tentang Statuta UGM dan Peraturan MWA Nomor 4 Tahun 2014 tentang Organisasi dan Tata Kelola UGM, terdiri atas (1) pengendalian tingkat kebijakan, (2) pengendalian tingkat operasional, dan (3) pengendalian pengawasan. Struktur manajemen risiko yang akan dibentuk menggunakan struktur organisasi UGM yang telah ada dengan melihat irisan tugas pokok dan fungsi masing-masing organ dan unit kerja.

Pengendalian tingkat kebijakan, biasa disebut komite risiko, dilakukan oleh Majelis Wali Amanat (MWA) melalui Komite Audit (KA). KA relevan mengampu peran komiter risiko karena salah satu tugasnya telah beririsan dengan fungsi komite risiko, yaitu melakukan analisis manajemen risiko sebagai bahan pertimbangan bagi MWA dalam memberikan persetujuan atau ratifikasi terhadap perjanjian menyangkut pemanfaatan kekayaan UGM. Tugas KA sebagai komite risiko adalah meninjau dan menyetujui kebijakan dan prosedur manajemen risiko organisasi, meninjau dan mengawasi kegiatan unit manajemen risiko, dan memantau serta me-review ketepatan informasi risiko yang diterima dari manajemen.

Pengendalian tingkat operasional dilakukan oleh rektor dibantu oleh Unit Manajemen Risiko (UMR) dan Unit Pemilik Risiko (UPR). UMR adalah unit yang berfungsi melakukan koordinasi dan proses manajemen risiko di tingkat universitas, sedangkan UPR berfungsi melakukan proses manajemen risiko di tingkat unit kerja. Tugas UMR adalah membuat kebijakan dan prosedur serta panduan manajemen risiko yang diperlukan, mengimplementasikan proses manajemen risiko, dan menelaah proses manajemen risiko yang dilakukan oleh UPR dan menyelaraskan risiko antar-UPR. Tugas UPR adalah melakukan proses manajemen risiko pada unit kerja termasuk unit-unit yang berada di bawahnya dan melaporkan hasilnya kepada UMR.

Fungsi UMR dijalankan oleh KAI dan Kantor Jaminan Mutu (KJM) dengan pertimbangan bahwa tugas pokok dan fungsi kedua unit tersebut bersinggungan dengan manajemen risiko. Fungsi UPR dilaksanakan oleh unit kerja selain KAI dan KJM.

Pengendalian tingkat pengawasan berfungsi memberikan penilaian independen atas efektivitas pelaksanaan manajemen risiko UGM, dilaksanakan oleh KA. Dalam menjalankan pengawasan, KA dapat menugaskan kantor akuntan publik atau kantor konsultan yang kompeten untuk melakukan penilian secara independen terhadap pelaksanaan manajemen 
risiko yang dilakukan oleh KJM dan KAI. KA juga dapat menugaskan KAI, khususnya fungsi audit KAI, untuk melakukan penilaian efektivitas pelaksanaan manajemen risiko atas KAI dan KJM dengan memperhatikan bahwa auditor internal yang terlibat dalam UMR dan UPR tidak dapat ditugaskan untuk melakukan penilaian guna menjaga independensi auditor KAI.

\section{Proses Manajemen Risiko UGM}

Proses manajemen risiko UGM menggunakan standar proses manajemen risiko Australia/New Zealand (AS/NZS) 31000:2009. Penggunaan kerangka AS/NZS 31000:2009 ini dengan pertimbangan sebagai berikut:

- Memberikan pendekatan sistematis dalam mengelola risiko guna mencapai tujuan organisasi.

- Dapat diterapkan pada semua jenis organisasi

- BPKP selaku pembina penyelenggaraan SPIP menyarankan penggunaan standar AS/NZS 31000:2009 untuk proses manajemen risiko.

- Telah digunakan oleh instansi pemerintah yaitu Kementerian Keuangan.

\section{Prosedur Manajemen Risiko}

Tujuan UGM memiliki tiga periode yang berbeda sehingga manajemen risiko UGM perlu dilakukan dengan tiga periode berdasarkan tujuan tersebut. Setidaknya UGM memiliki tiga tujuan berbeda berdasarkan durasi waktu tujuan tersebut; yaitu lima tahun, satu tahun, dan waktu tertentu. Tujuan dengan durasi waktu lima tahun adalah tujuan yang tertera dalam rencana strategis (Renstra) UGM. Renstra disusun setiap lima tahun sekali oleh Rektor UGM yang baru dan berlaku untuk masa jabatannya. Tujuan dengan durasi waktu satu tahun adalah tujuan yang tercantum dalam kontrak kinerja antara UGM dengan Kemenristekdikti, kontrak kinerja diperbarui setiap tahun. Tujuan dengan waktu tertentu adalah tujuan dari program yang diamanatkan oleh pemerintah dan/atau mitra kepada UGM dengan durasi waktu tertentu sesuai ketentuan atau kesepakatan. Oleh karena itu, periodesasi manajemen risiko UGM perlu dibedakan menjadi 3 hal berikut ini.

- Prosedur manajemen risiko periode lima tahunan.

- Prosedur manajemen risiko periode satu tahunan.

- Prosedur manajemen risiko periode waktu tertentu.

Masing-masing prosedur manajemen risiko tersebut disusun berdasarkan 7 proses manajemen risiko AS/NZS 31000:2009 sebagaimana dijabarkan di atas.

\section{Prosedur Manajemen Risiko Periode Lima Tahunan}

Prosedur manajemen risiko periode lima tahunan adalah periode pelaksanaan manajemen risiko yang dilakukan selama lima tahun setelah MWA menetapkan renstra baru. Usaha pencapaian tujuan yang tertera dalam renstra akan menghadapi berbagai risiko, oleh karena itu perlu dilakukan manajemen risiko sehingga tujuan tersebut dapat dicapai. Langkah-langkah manajemen risiko yang dilakukan dalam periode ini meliputi hal berikut di bawah ini.

a) Penyusunan dan Penetapan Regulasi

Proses penyusunan regulasi, identifikasi, analisis, dan evaluasi risiko dideskripsikan pada gambar yang disajikan dalam Lampiran 3. Setelah MWA menetapkan rencana strategis (Renstra) UGM, UMR menyusun draf regulasi manajemen risiko, terdiri atas kebijakan, prosedur, dan panduan pelaksanaan manajemen risiko. Regulasi ini menjadi dasar dan panduan bagi UMR dan UPR dalam melaksanakan proses manajemen risiko. Materi dalam draf regulasi, antara lain sebagai berikut.

i. Struktur manajemen risiko.

ii. Proses manajemen risiko.

iii. Skala kemungkinan.

iv. Skala dampak.

v. Kriteria penerimaan risiko.

UMR mengajukan draf regulasi kepada rektor untuk ditelaah lebih lanjut. Jika rektor tidak menyetujui draf regulasi tersebut, maka UMR akan merevisi sesuai arahan rektor. Sebaliknya, jika rektor telah menyetujui draf tersebut, maka rektor akan mengajukannya kepada KA.

Setelah menerima draf regulasi manajemen risiko dari rektor, KA menelaah dan menetapkan draf tersebut menjadi regulasi manajemen risiko UGM. Jika KA belum menyetujui, maka KA mengembalikan kepada UMR melalui rektor untuk direvisi dan diserahkan kembali kepada KA untuk penelaahan lebih lanjut dan persetujuan. KA menyerahkan regulasi manajemen risiko yang telah disetujui kepada rektor. Rektor menyerahkan regulasi manajemen risiko kepaa UMR dan UPR untuk pelaksanaannya.

b) Proses Manajemen Risiko

UMR menginisiasi dan mengoordinasi proses manajemen risiko yang dilakukan oleh UPR. UPR menetapkan konteks manajemen risiko untuk unit kerjanya, mengidentifikasi risiko, menganalisis risiko, dan mengevaluasi risiko sehingga menghasilkan draf profil risiko UPR.

c) Review dan Penyelarasan Risiko antarunit Kerja 
UPR menyerahkan draf profil risiko UPR kepada UMR untuk proses kompilasi, review, dan sinkronisasi profil risiko. UMR mengompilasi seluruh draf profil risiko UPR dan me-review kelengkapan informasi risiko dari setiap UPR. UMR menelaah hubungan suatu risiko dengan risiko lainnya dalam suatu UMP, hubungan suatu risiko pada suatu UPR dengan risiko dalam UPR lain, dan suatu risiko UPR dengan proses bisnis dan regulasi yang ada di unit kerja lain. Telaah hubungan risiko ini dilakukan untuk sinkronisasi risiko sehingga menghasilkan draf profil risiko UGM yang komprehensif. UMR mengajukan draf profil risiko UGM kepada rektor untuk penelaahan dan persetujuan, selanjutnya draf profil risiko diserahkan ke KA.

d) Penetapan Profil Risiko

KA melakukan review dan penetapan profil risiko UGM. Salah satu tugas KA adalah: "Memantau serta melakukan review ketepatan informasi risiko yang diterima dari manajemen." Oleh karena itu, KA perlu melakukan review draf profil risiko UGM (di dalamnya terdapat draf risiko unit kerja yang diajukan oleh rektor dan UMR). KA menelaah ketepatan draf profil risiko berdasarkan kebijakan manajemen risiko yang telah ditetapkan oleh KA. KA menetapkan draf profil risiko UGM menjadi profil risiko UGM untuk periode lima tahun dan mendistribusikannya kepada rektor dan UMR. UMR memilah data profil risiko masing-masing UPR dan mendistribusikannya kepada UPR.

e) Penetapan Kebijakan Penanganan Risiko

Berdasarkan profil risiko UGM, KA menyusun kebijakan penanganan risiko UGM yang menjadi dasar UMR dan UPR dalam melakukan penanganan risiko. KA menyerahkan kebijakan penanganan risiko kepada rektor dan UMR.

f) Pelaksanaan Penanganan Risiko

Berdasarkan kebijakan penanganan risiko, UMR menyusun dan melaksanakan program penanganan risiko untuk level universitas. Selain itu, UMR mengoordinasikan proses penanganan risiko yang dilakukan oleh UPR. Detail proses penanganan risiko diulas pada subbab Proses Manajemen Risiko UGM.

g) Pelaporan Pelaksanaan Penanganan Risiko

Setelah melaksanakan proses penanganan risiko selama lima tahun, di akhir masa berlakunya renstra, UMR menyusun draf laporan pelaksanaan manajemen risiko. Draf laporan ini merupakan kompilasi dari laporan pelaksanaan yang dilakukan oleh UMR dan UPR setelah dilakukan review dan disinkronisasi sehingga menjadi laporan penanganan risiko yang komprehensif. UMR menyerahkan draf laporan manajemen risiko kepada rektor. Jika rektor menyetujui, draf tersebut akan diserahkan kepada KA. Sebaliknya, jika rektor tidak menyetujui, maka akan dikembalikan kepada UMR untuk direvisi dan diajukan kembali kepada rektor untuk mendapatkan persetujuan.

h) Pemantauan dan reviu

UMR melakukan pemantauan dan review atas risiko dan program penanganan risiko pada setiap akhir tahun anggaran untuk memastikan bahwa risiko dan penanganannya selaras dengan perubahan di dalam lingkungan UGM. Pemantauan dan review dilakukan, baik oleh UMR maupun UPR, dengan melakukan ulang langkah-langkah prosedur manajemen risiko sebagaimana telah dijelaskan di atas. Hasil pelaksanaan pemantauan dan review dilaporkan oleh UMR kepada KA melalui rektor.

\section{Prosedur Manajemen Risiko Periode Satu Tahunan}

Prosedur manajemen risiko periode satu tahunan adalah periode pelaksanaan manajemen risiko yang dilakukan untuk mengelola risiko atas perikatan dengan masa waktu satu tahun anggaran. Pembahasan ini mengkhususkan pada kontrak kinerja antara UGM dengan Kemenristekdikti. Perikatan antara UGM dengan pihak lain yang berdurasi waktu satu tahun anggaran mungkin ada beberapa, namun informasi yang berhasil diperoleh peneliti adalah kontrak kinerja antara UGM dengan Kemenristekdikti. Untuk menyederhanakan pembahasan, manajemen risiko periode satu tahunan dikhususkan hanya untuk mengelola risiko atas kontrak kinerja antara UGM dengan Kemenristekdikti. Proses manajemen risiko dimulai saat dokumen kontrak kinerja ditandatangani oleh kedua belah pihak (disahkan). Langkah-langkah manajemen risiko yang dilakukan dalam periode ini meliputi hal berikut ini, bagan alir proses disajikan dalam Lampiran 4.

a. Proses manajemen risiko, meliputi penetepan konteks, identifikasi risiko, analisis risiko, dan evaluasi risiko.

b. Review dan penyelarasan risiko antarunit kerja.

c. Penetapan profil risiko.

d. Pelaksanaan penanganan risiko.

e. Pelaporan pelaksanaan penanganan risiko.

Langkah manajemen risiko periode satu tahunan dimulai saat dokumen kontrak kinerja disahkan. Rektor menyerahkan dokumen kontrak kinerja kepada UMR. Setelah mempelajari isi kontrak kinerja, UMR menganalisis dan menentukan unit kerja atau UPR mana yang akan terlibat. UMR menginstruksikan UPR yang terlibat untuk melakukan proses manajemen 
risiko dengan mengirimkan surat instruksi dilampiri dokumen kontrak kinerja.

Setelah menerima instruksi dari UMR, UPR melakukan proses penetapan konteks, identifikasi risiko, analisis risiko, dan evaluasi risiko dengan berpedoman pada regulasi yang ditetapkan oleh KA. Proses ini menghasilkan draf profil risiko UPR. UPR menyerahkan draf profil risiko kepada UMR untuk diperoses lebih lanjut.

UMR mengompilasi seluruh draf profil risiko UPR dan melakukan review kelengkapan informasi risiko dari tiap-tiap UPR. UMR menelaah hubungan suatu risiko dengan risiko lainnya dalam suatu UMP, hubungan suatu risiko pada suatu UPR dengan risiko dalam UPR lain, dan suatu risiko UPR dengan proses bisnis serta regulasi yang ada di unit kerja lain. Telaah hubungan risiko ini dilakukan untuk sinkronisasi risiko sehingga menghasilkan draf profil risiko UGM yang komprehensif. UMR mengajukan draf profil risiko UGM kepada rektor untuk penelaahan dan persetujuan. Setelah rektor menyetujui draf profil risiko, rektor menyerahkan profil risiko UGM kepada KA sebagai laporan dan kepada UMR untuk proses penanganan.

\section{Prosedur Manajemen Risiko Periode Waktu Tertentu}

Prosedur manajemen risiko periode waktu tertentu adalah periode pelaksanaan manajemen risiko, dilakukan untuk mengelola risiko atas perikatan dengan masa waktu kurang atau sama dengan atau lebih dari satu tahun anggaran. Terdapat beberapa jenis pelaksanaan perikatan sebagai berikut.

a. Perikatan antara UGM dengan mitra dan dilaksanakan oleh tim ad hoc.

b. Perikatan antara UGM dengan mitra dan dilaksanakan oleh satu atau lebih unit kerja.

c. Perikatan antara unit kerja dengan mitra dan dilaksanakan oleh satu atau lebih unit kerja.

Proses manajemen risiko dimulai saat dokumen perikatan ditandatangani oleh kedua belah pihak (disahkan). Langkah-langkah manajemen risiko yang dilakukan dalam periode ini meliputi hal berikut ini, bagan alir prosedur ini disajikan dalam Lampiran 5 .

a. Proses manajemen risiko, meliputi penetapan konteks, identifikasi risiko, analisis risiko, evaluasi risiko, dan penanganan risiko.

b. Review profil risiko.

c. Pelaporan pelaksanaan penanganan risiko.

Untuk perikatan jenis pertama dan jenis kedua, proses manajemen risiko dilakukan dengan langkahlangkah yang sama. Untuk mempermudah proses manajemen risiko, pada perikatan jenis kedua dibentuk tim ad hoc, ditugaskan melakukan manajemen risiko bersama-sama dengan UMR.

Proses manajemen risiko dimulai setelah perikatan ditandatangani oleh kedua belah pihak atau dinyatakan berlaku. Berdasarkan dokumen perikatan, UMR bersama-sama dengan tim ad hoc melakukan proses manajemen risiko, meliputi penetapan konteks, identifikasi, analisis, dan evaluasi risiko. Proses penanganan risiko dilakukan oleh tim ad hoc dengan supervisi UMR. Proses manajemen risiko yang dilakukan oleh tim ad hoc dan UMR berdasarkan regulasi yang ditetapkan oleh KA. Proses ini menghasilkan laporan profil risiko dan laporan penanganan risiko, diserahkan kepada rektor sebagai laporan. Rektor dapat menyerahkan laporan profil risiko dan laporan penanganan risiko kepada KA sebagai laporan.

Dalam perikatan jenis ketiga, proses manajemen risiko dimulai setelah perikatan ditandatangani oleh kedua belah pihak atau dinyatakan berlaku. Berdasarkan dokumen perikatan, unit kerja (UPR) melakukan proses manajemen risiko, meliputi penetapan konteks, identifikasi, analisis, dan evaluasi risiko sehingga menghasilkan draf profil risiko kegiatan. UPR menyerahkan draf profil risiko kegiatan kepada UMR untuk dilakukan review dan dianalisis program penanganannya sehingga menghasilkan profil risiko dan program penanganan risiko kegiatan. Profil risiko dan program penanganan risiko kegiatan tersebut menjadi dasar bagi UPR dalam melakukan penanganan risiko. Proses penanganan risiko (dilakukan oleh UPR) menghasilkan laporan pelaksanaan penanganan risiko. Laporan pelaksanaan penanganan tersebut diserahkan oleh UPR kepada UMR sebagai laporan. UMR dapat menyerahkan laporan pelaksanaan penanganan risiko kepada rektor sebagai laporan (jika dibutuhkan).

Proses pemantauan dan review untuk manajemen risiko waktu tertentu dilakukan oleh UMR secara periodik. UMR mengembangkan dan merencanakan kecukupan intensitas pemantauan dan review berdasarkan profil risiko yang dihasilkan dalam proses identifikasi dan analisis serta evaluasi risiko.

Proses komunikasi dan konsultasi dilakukan secara melekat dalam proses manajemen risiko dan pelaporannya. Selama melakukan proses manajemen risiko, tim ad hoc dan UMR saling berkomunikasi guna menyamakan persepsi. Pelaporan pelaksanaan penanganan risiko merupakan bagian dari proses komunikasi kepada rektor. 


\section{Penutup}

Berdasarkan analisis dan pembahasan yang disajikan dan diulas pada bab sebelumnya, dapat ditarik beberapa simpulan sebagai berikut:

a. Sistem manajemen risiko di UGM membutuhkan struktur, proses, dan prosedur manajemen risiko.

b. Struktur manajemen risiko UGM dapat menggunakan model tiga tingkatan pengendalian:

a) Pengendalian tingkat kebijakan dijalankan oleh Komite Audit.

b) Pengandalian tingkat operasional dilakukan oleh rektor dan dibantu oleh unit manajemen risiko (UMR) dan unit pemilik risiko (UPR). UMR dijalankan oleh Kantor Jaminan Mutu dan Kantor Audit Internal. Sedangkan UPR dijalankan oleh unit kerja.

c) Pengendalian Tingkat Pengawasan yang dilakukan oleh KA

d) Proses manajemen risiko UGM dapat mengadopsi standar proses manajemen risiko AS/NZS 31000:2009, terdiri dari proses; penetapan konteks, identifikasi risiko, analisis risiko, evaluasi risiko, penanganan (perlakuan) risiko, pemantauan dan review, serta komunikasi dan konsultasi.

c. Prosedur manajemen risiko UGM terdiri atas tiga prosedur yang dibedakan berdasarkan periode tujuan UGM, yaitu prosedur lima tahunan, prosedur satu tahunan, dan prosedur waktu tertentu.

Berdasarkan analisis dan pembahasan dalam Bab IV dapat ditarik beberapa simpulan/beberapa rekomendasi sebagai berikut:

a. UGM perlu menetapkan struktur organisasi manajemen risiko sebagaiman dijelaskan dalam kesimpulan.

b. Disarankan agar UGM mengadopsi standar proses manajemen risiko AS/NZS 31000:2009.

UGM perlu menyusun dan menjalankan beberapa prosedur manajemen risiko yang dibedakan berdasarkan periode tujuan UGM, yaitu prosedur lima tahunan, prosedur satu tahunan, dan prosedur waktu tertentu.

\section{References}

Ariff, Mohd Shoki Bin Md., dkk. (2014). A Framework for Risk Management Practices and Organizational Performance in Higher Education. Review of Integrative Business \& Economics Reserch.
Goverment of Western Australia. (2007). Can You Risk It? An Introduction to Risk Management for Community Organisations, Perth Western Australia.

Griffiths, Phil. (2005). Risk Based Auditing. Burlington, Gower Publishing Company.

Hanafi, M.M. (2006). Manajemen Risiko. Yogyakarta: UPP STIM YKPN.

Helsloot, I. dan Jong, W. (2006). Risk Management in Higher Education and Research in the Netherlands. Journal of Contingencies \& Crisis Management.

Hoyt, R.E. dan Liebenberg, A.P. (2010). The Value of Enterprise Risk Management. SSRN eLibrary.

Jogiyanto, (2004), Metodologi Penelitian Bisnis: Salah Kaprah dan Pengalaman-pengalaman. Yogyakarta: BPFE.

Joint Australian New Zealand International Standard (AS/NZS ISO 31000:2009). (2009). Risk Management - Principles and Guidelines. Sydney.

Miles, M.B. dan Huberman, M.A. (1984). Qualitative Data Analysis; A Sourccebook of New Method. London: Beverly Hills, Sage Publications.

Moeller, R.R. (2007). COSO Enterprise Risk Management Understanding the New Integrated ERM Framework. Canada: John Wiley \& Sons, Inc.

Moeller, R.R. (2011). COSO Enterprise Risk Management: Establishing Effective Governance, Risk, And Compliance Processes Second. New Jersey: John Wiley \& Sons, Inc.

Rejda, G.E. (2006). Principles of Risk Management and Insurance. India: Dorling Kindersley.

Sugiyono. (2007). Memahami Penelitian Kualitatif. Bandung: Alfabeta.

The Institute of Risk Management (IRM) dan The Association of Insurance and Risk Managers (AIRMIC). (2002). Risk Management Standard.

Thomas, Bill. (2010). ERM from the Ground Up: A Grass Roots Approach - Integrating Enterprise Risk Management into California State University San Marcos Athletics. University Risk Management and Insurance Association (URMIA) Journal.

Undang-Undang Nomor 12 Tahun 2012 tentang Pendidikan Tinggi.

Peraturan Pemerintah Nomor 153 Tahun 2000 tentang Penetapan Universitas Gadjah Mada sebagai Badan Hukum Milik Negara.

Peraturan Pemerintah Nomor 23 Tahun 2005 tentang Pengelolaan Keuangan Badan Layanan Umum.

Peraturan Pemerintah Nomor 60 Tahun 2008 tentang Sistem Pengendalian Intern Pemerintah.

Peraturan Pemerintah Nomor 67 Tahun 2013 tentang Statuta Universitas Gadjah Mada. 
Peraturan Pemerintah Nomor 16 Tahun 2014 tentang Statuta Universitas Sumatera Utara.

Peraturan Pemerintah Nomor 30 Tahun 2014 tentang Statuta Universitas Airlangga.

Peraturan Pemerintah Nomor 51 Tahun 2015 tentang Statuta Universitas Padjajaran

Peraturan Pemerintah Nomor 52 Tahun 2015 tentang Statuta Universitas Diponegoro.

Peraturan Pemerintah Nomor 53 Tahun 2015 tentang Statuta Universitas Hasanuddin.

Peraturan Pemerintah Nomor 54 Tahun 2015 tentang Statuta Institut Teknologi Sepuluh November.

Peraturan Menteri Keuangan Nomor 191/PMK.09/2008 tentang Penerapan Manajemen Risiko di Lingkungan Depertemen Keuangan. 